\title{
Struggle in struggle: Surgical treatment of Leriche syndrome in a horseshoe kidney patient
}

\author{
Mücadele içinde mücadele: At nalı böbrek hastasında Leriche sendromunun cerrahi tedavisi
}

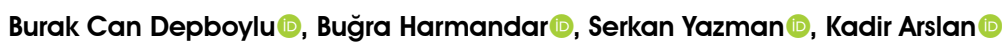

Institution where the research was done:

Muğla Sııkı Koçman University Faculty of Medicine, Muğla, Turkey

Department of Cardiovascular Surgery, Muğla Sıtkı Koçman University Faculty of Medicine, Muğla, Turkey

\begin{abstract}
Coexistence of infrarenal aortic occlusion, known as Leriche syndrome, and horseshoe kidney is extremely rare. The isthmus of the latter, which usually contains functional renal parenchyma, complicates surgery. A 52-year-old male patient with Leriche syndrome and concomitant horseshoe kidney disease underwent a successful surgical repair. A median incision and transperitoneal approach were used to explore the infrarenal aorta, aortoiliac bifurcation, iliac arteries, and horseshoe kidney. The isthmus was connecting the lower poles over the aortoiliac bifurcation. Aortoplasty with aortobifemoral bypass was performed, preserving the horseshoe kidney and its accessory arteries. Operative and postoperative periods were uneventful. At eight months of follow-up, the patient was asymptomatic in daily activities.
\end{abstract}

Keywords: Abdominal, aorta, aortic diseases, fused kidney, leriche syndrome, surgery, urogenital abnormalities.

As the most common congenital abnormality of the kidneys, horseshoe kidney (HSK) accounts for 0.15 to $0.25 \%$ of the population and found in $1 / 710$ autopsy studies. ${ }^{[1,2]}$ It is seen two-times higher in males. ${ }^{[1]}$ Despite being reported in twins and siblings, any genetic or racial determination is unknown. In HSK, fusion of the kidneys is mostly seen at lower poles over the distal abdominal aorta (AA) and/or aortoiliac bifurcation (AIB). Connection of the poles may either occur from fibrous band or contain

\section{$\ddot{O} Z$}

Leriche sendromu olarak bilinen infrarenal aort tıkanıklı̆g 1 ve at nalı böbreğin birlikteliği son derece nadirdir. Genellikle fonksiyonel renal parankim içeren at nalı böbreğin boynu, cerrahiyi daha da zorlaştırır. Leriche sendromu ve eş zamanlı at nalı böbrek hastalığı olan 52 yaşında erkek hastaya başarılı bir cerrahi onarım yapıldı. İnfrarenal aort, aortoiliyak bifürkasyon, iliyak arterler ve at nalı böbreği eksplore etmek için median insizyon ve transperitoneal yaklaşım kullanıldı. Boyun aortoiliyak bifürkasyonun üzerinde alt kutupları birbirine bağliyordu. At nalı böbrek ve aksesuvar arterler korunarak, aortoplasti ve aortobifemoral baypas yapild. Ameliyat ve ameliyat sonrası dönemler sorunsuzdu. Takibin sekizinci ayında, hasta günlük aktivitelerinde asemptomatik idi.

Anahtar sözcükler: Abdominal, aort, aort hastalıkları, kaynaşmış böbrek, leriche sendromu, ameliyat, ürogenital anormallikler.

functional parenchymal tissue. Also, the arterial supply of the HSK shows a wide variation. Renal arteries may arise from the AA, common iliac arteries (CIAs), and inferior mesenteric artery (IMA). ${ }^{[2]}$

Aortoiliac occlusive disease, also commonly referred to as Leriche syndrome (LS), is a rare and potentially devastating chronic disease which results from obstructing atherosclerotic plaque formation of the infrarenal AA. Decreased distal pulses, claudication, and erectile dysfunction is the typical triad in males.

Received: March 26, 2019 Accepted: August 21, 2019 Published online: October 23, 2019

Correspondence: Burak Can Depboylu, MD. Muğla Sıtkı Koçman Üniversitesi Tıp Fakültesi, Kalp ve Damar Cerrahisi Anabilim Dalı, 48000 Gülağzı, Muğla, Turkey. Tel: +90 $252-2115173$ e-mail: burakdepboylu@yahoo.com 
The incidence of LS is estimated to be $0.15 \%$ in the overall population wordlwide with a mortality rate ranging between 25 and $75 \%{ }^{[3]}$

Surgical revascularization is the standard treatment of LS. Although axillobifemoral bypass can be performed, aortobifemoral bypass surgery is the most common type of anatomic procedure. There is no data regarding the effects of HSK on the development of atherosclerosis. Coexistence of LS and HSK is extremely rare. Placement of the HSK isthmus, lying over the occluded AA segment, makes its exposure extremely difficult. In addition, complex anatomical anomalies of the kidneys and their collecting systems and arteries complicate cross-clamping of the AA and aortic graft anastomosis.

Herein, we present a rare case of concomitant LS and HSK successfully treated and discuss our surgical approach in the light of literature data.

\section{CASE REPORT}

A 52-year-old male patient was admitted to our hospital with the complaints of claudication in pelvis and legs in 50 meters. On physical examination, both lower limb pulses including the femoral arteries were non-palpable. No ischemic coldness, paleness and/or wounds were present in lower limbs. Ankle brachial indexes were 0.35 for the right and 0.40 for the left lower limb. The patient also reported impotence. Computed tomography angiography (CTA) revealed distal AA occlusion, including the CIA and internal iliac arteries. Also, a coexisting HSK was present, lying over the occluded AA segment and AIB (Figure 1). The presented case herein was in Class II according to the Leriche-Fontaine classification and type $\mathrm{C}$ according to the TransAtlantic Inter-Society Consensus (TASC). Our case was classified as Papin III and Crawford III. Preoperative urea and creatinine levels were $20.4 \mathrm{mg} / \mathrm{dL}$ and $0.62 \mathrm{mg} / \mathrm{dL}$, respectively. Surgical repair was decided. A written informed consent was obtained from the patient.

Operation was performed through a median abdominal incision. Using transperitoneal approach, HSK and AIB were explored in excessive retroperitoneal fat tissue with a difficult dissection. Accessory arteries arising from the external and internal iliac arteries feeding the isthmus mass and HSK were identified. Due to possible severe bleeding and renal function loss after separation of isthmus, division of the HSK isthmus was avoided and the

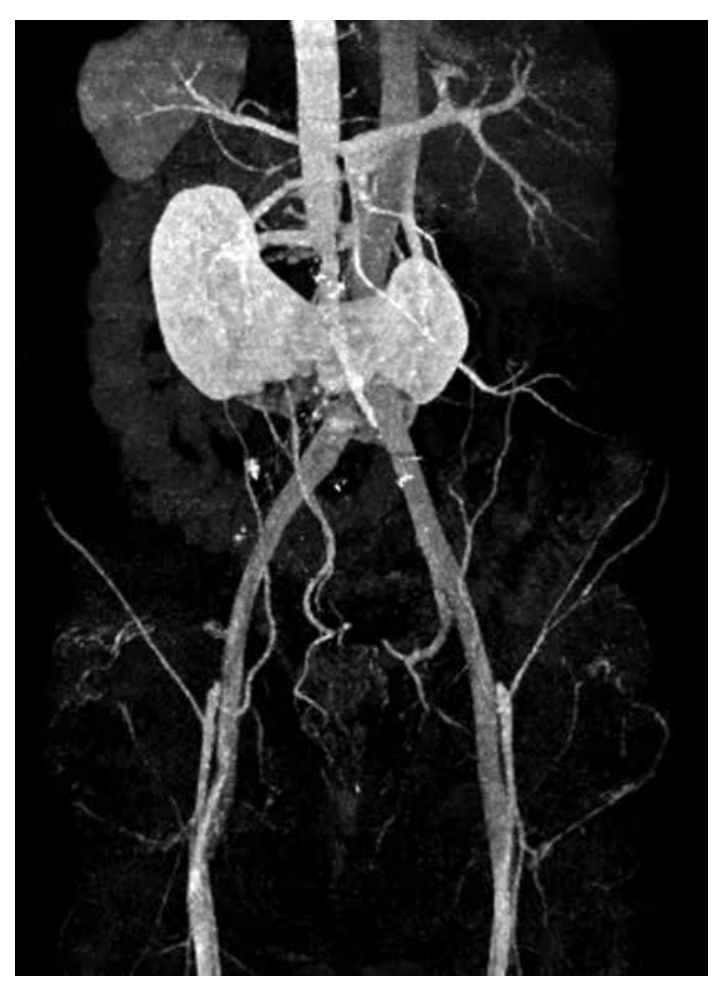

Figure 1. A preoperative computed tomography angiography image showing horseshoe kidney, its accessory arteries, and aortoiliac occlusions.

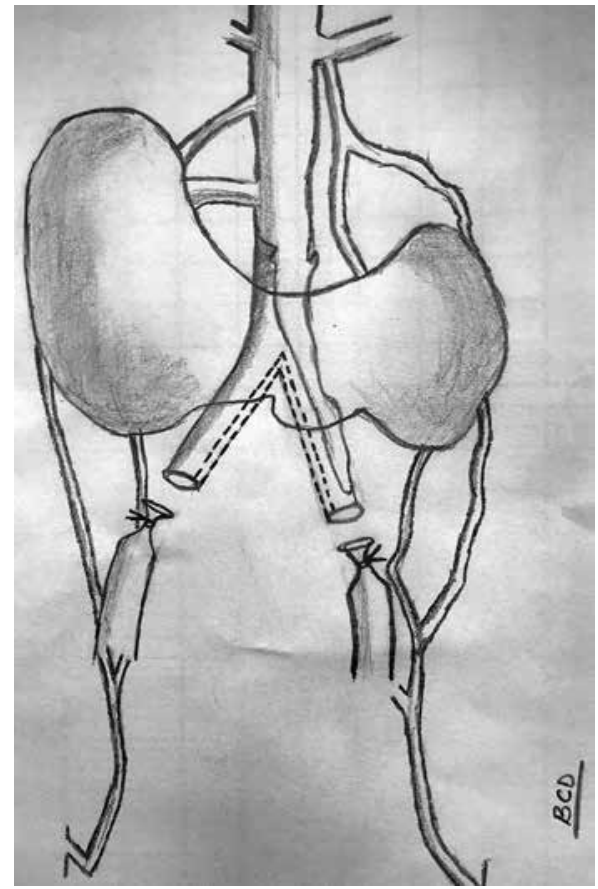

Figure 2. An intraoperative demonstration of procedure. Both common iliac arteries were ligated and separated. Medial parts of common iliac arteries including aortoiliac bifurcation were incised. 


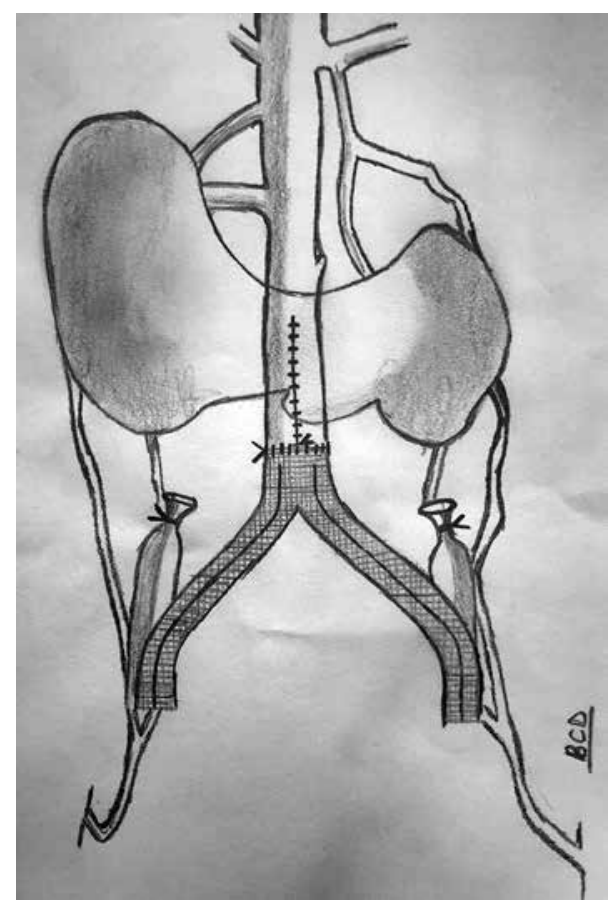

Figure 3. An intraoperative demonstration of procedure. Common iliac arteries were combined by suturing from anterior and posterior divisions in a tubular shape to extend distal aorta out of horseshoe kidney location. Then, a 16/8-mm Dacron Y graft was anastomosed to the end of distal aorta.

whole HSK was preserved. After heparinization, HSK was elevated as much as possible and a Satinsky cross-clamp (B. Braun Aesculap, 78532 Tuttlingen, Germany) was placed to the AA under the HSK. The CIAs were ligated and separated. Medial parts of the CIAs including the AIB were incised (Figure 2). Atherosclerotic plaque formations in the CIAs and AA were removed. The CIAs were combined by suturing from the anterior and posterior divisions in a tubular shape to extend the distal AA out of the HSK location (Figure 3). Then, a 16/8-mm Dacron Y graft was used to anastomose the end of the elongated AA. Graft limbs were anastomosed to the common femoral arteries (CFAs) after careful tunneling via separate femoral incisions.

There was no complication during the operation or in the postoperative course. Urea and creatinine levels were $21.4 \mathrm{mg} / \mathrm{dL}$ and $0.58 \mathrm{mg} / \mathrm{dL}$, respectively in the postoperative first day. The patient was discharged in a well condition on Day 10. Repeated CTA at eight months of follow-up showed no abnormal findings (Figure 4) and the patient was asymptomatic without any complaints.

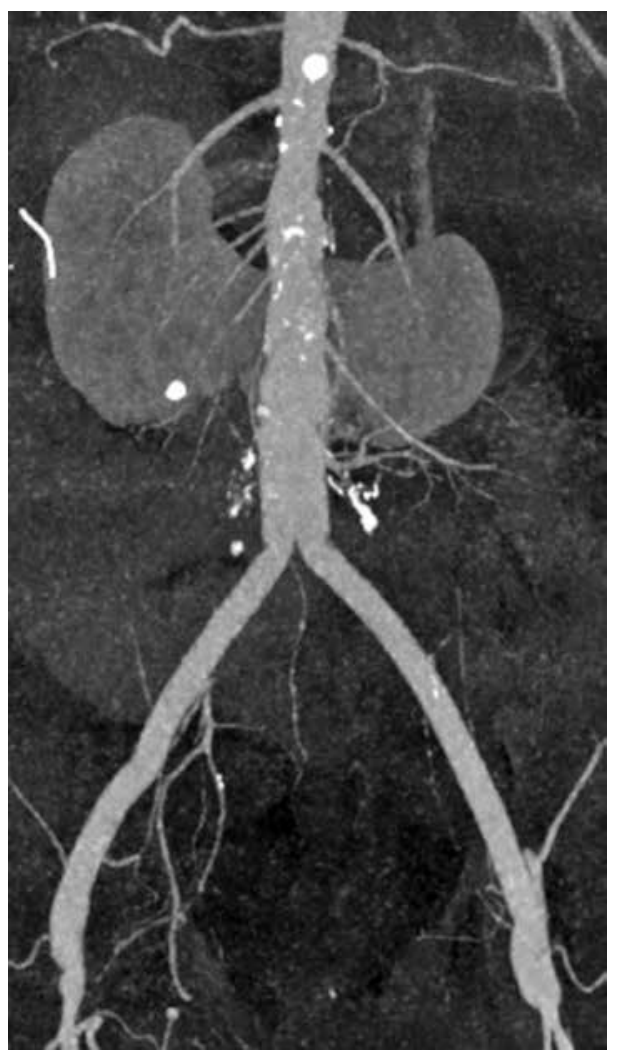

Figure 4. A postoperative computed tomography angiography of patent aortobifemoral bypass graft at eight months.

\section{DISCUSSION}

Endovascular interventions or surgical repairs of the lower limbs are the classical treatments of LS. Axillobifemoral bypass may provide excellent patency in short-term. ${ }^{[4]}$ The occluded segment was involving the distal AA, AIB, CIAs, and internal and external iliac arteries through the CFAs. In case of coexisting HSK, surgery requires a detailed information of anatomical and vascular structures. In $95 \%$ of patients with HSK, kidneys are connected to the lower poles, usually with a parenchymatous isthmus in front of the AA and AIB and, in $75 \%$ of the patients, accessory arteries are present which may be important for HSK and may complicate the aortic surgery. ${ }^{[5]}$

The Papin`s and Crawford's classifications are the two main classifications for HSK. Accessory arteries arising from the iliac arteries and AA were visualized with preoperative CTA, were explored, and protected during surgery, but did not hinder our approach to AIB underlying HSK. However, due to possible anomalies of the Gerota's and Zuckerkandl's fascias which separate the peri- and pararenal fat 
tissue in the retroperitoneal space, the retroperitoneal space was full of excessive fat tissue which made the exploration of the anatomical structures more difficult. In cases which transperitoneal approach was used, some authors recommended the transection of the isthmus of HSK. ${ }^{[5]}$ However, if the isthmus of HSK consists of functional renal tissue, its transection may cause to renal necrosis, urinary leakage, hemorrhage, sepsis, and renal insufficiency in the postoperative period. ${ }^{[6]}$ Therefore, we avoided dividing the HSK isthmus and performed surgery under this structure. In the literature, reports of AA aneurysm surgery with concomitant HSK have been mostly described. However, there is a limited number of reports of surgical treatment of LS with concomitant HSK. Dorweiler et al ${ }^{[3]}$ performed the proximal anastomosis of the Y graft to the higher part of AA, passed the graft legs under the HSK isthmus and performed distal anastomosis to the CFAs. Additionally, they implanted a 6-mm graft to the patent IMA. In our case, there were accessory arteries of the HSK in the higher part of the aorta which enabled us to place a cross-clamp and perform the proximal anastomoses of the Y graft. On the other hand, angulation of the Y graft while passing over the HSK may cause kinking of the graft and/or legs of the graft which cause to their thrombosis. Due to the limited reports of LS with concomitant HSK, this case report may help young surgeons for the surgical approach and technique in such cases.

In conclusion, coexistence of LS and HSK is extremely rare. The latter makes the surgical repair of LS even more difficult. A detailed preoperative evaluation is needed to decrease postoperative complications. Despite all preoperative preparations, exploration of the surgical area and graft anastomosis may be challenging.

\section{Declaration of conflicting interests}

The authors declared no conflicts of interest with respect to the authorship and/or publication of this article.

\section{Funding}

The authors received no financial support for the research and/or authorship of this article.

\section{REFERENCES}

1. Kolbakır F, Yucel SM, Asc1 R. The repair of abdominal aortic aneurysm in patient with horseshoe kidney-nephrolithiasis. Turkish J Vasc Surg 2008;17:27-30.

2. Natsis K, Piagkou M, Skotsimara A, Protogerou V, Tsitouridis I, Skandalakis P. Horseshoe kidney: a review of anatomy and pathology. Surg Radiol Anat 2014;36:517-26.

3. Dorweiler B, Neufang A, Schmiedt W, Oelert H. Distal aortic occlusion and horse shoe kidney: vascular reconstruction with aortobifemoral bypass. EJVES Extra 1, 2001;3:41-3.

4. Clair DG, Beach JM. Strategies for managing aortoiliac occlusions: access, treatment and outcomes. Expert Rev Cardiovasc Ther 2015;13:551-63.

5. Hidiroglu M, Kunt A, Cetin L. Management of an abdominal aortic aneurysm in a patient with horseshoe kidney: case report. Turk J Vasc Surg 2009;18:32-5.

6. Davidovic LB, Markovic M, Kostic D, Zlatanovic P, Mutavdzic P, Cvetic V. Open repair of ruptured abdominal aortic aneurysm with associated horseshoe kidney. Int Angiol 2018;37:471-8. 